\title{
Nye perorale antikoagulasjonsmidler - en oversikt
}

\begin{abstract}
BAKGRUNN Dabigatran, rivaroksaban og apiksaban er tre nye perorale antikoagulasjonsmidler som nylig er blitt godkjent i Norge. Hensikten med denne artikkelen er å gi en oversikt over virkningsmekanismene og de viktigste indikasjonene og komme med praktiske råd ved bruk av disse medikamentene.
\end{abstract}

KUNNSKAPSGRUNNLAG Denne oversikten er basert på publiserte fase 3-studier, litteratursøk i PubMed og forfatternes kliniske erfaring.

RESULTATER Indikasjoner for bruk av de nye antikoagulasjonsmidlene omfatter tromboseprofylakse etter hofte- og kneleddskirurgi (alle tre), forebygging av slag og systemisk embolisme ved ikke-valvulær atrieflimmer (alle tre), behandling av akutt venøs trombose og sekundærprofylakse etter venøs trombose (foreløpig kun rivaroksaban). For de nevnte indikasjonene har det vist seg at medikamentene ikke er dårligere enn standard etablert antikoagulasjonsbehandling. Ved atrieflimmer har alle de tre medikamentene også gitt lavere forekomst av intrakraniale blødninger enn standard behandling.

FORTOLKNING Det er viktig at midlene kun gis på godkjente indikasjoner, at man selekterer pasienter med god etterlevelse, utelukker kontraindikasjoner og kartlegger medikamentinteraksjoner. Koagulasjonseffekten behøver ikke monitorering, men pasientene bør følges opp med regelmessige legekonsultasjoner for å avdekke tilstander som kan føre til endringer i forventet effekt eller sikkerhet.

Antikoagulasjonsbehandling er nødvendig for å forebygge og behandle en rekke tromboemboliske tilstander. Det er velkjent at warfarinbehandling effektivt beskytter mot trombose, men behandlingen vanskeliggjøres av smalt terapeutisk vindu, stor doserespons-variasjon, mange interaksjoner og behov for INR-måling.

Det har derfor foregått omfattende forskning med henblikk på å utvikle perorale antikoagulantia som kan gis i en fast dose uten behov for monitorering av koagulasjonseffekten. Store legemiddelutprøvningsprogrammer er enten under gjennomføring eller er allerede gjennomført (1). Foreløpig har medikamentene dabigatran, rivaroksaban og apiksaban fått markedsføringstillatelse i Norge.

Hensikten med denne artikkelen er å gi en oversikt over virkningsmekanismene, status for utprøvning og indikasjoner samt formidle praktiske opplysninger vedrørende bruk av disse medikamentene.

\section{Kunnskapsgrunnlag}

Artikkelen er basert på publiserte fase 3-studier med medikamentene dabigatran, rivaroksaban og apiksaban samt klinisk erfaring med disse. Vi supplerte med litteratursøk i PubMed for å sikre oss at vi hadde fått med alle fase 3-studier.

\section{Virkningsmekanismer}

Dabigatran, rivaroksaban og apiksaban er små molekyler som er utviklet for å hemme enten aktivert koagulasjonsfaktor II (trom- bin) eller aktivert faktor $\mathrm{X}$ direkte (fig 1) Tabell 1 gir en oversikt over de viktigste farmakokinetiske og farmakodynamiske egenskapene (2).

Alle de tre medikamentene har en forutsigbar og doseavhengig plasmakonsentrasjon etter peroralt inntak. Så langt vi kjenner til påvirkes absorpsjonen lite av matinntaket. Maksimal plasmakonsentrasjon oppnås raskt (etter 1-4 timer), mens halveringstiden varierer fra åtte til 17 timer (1).

\section{Klinisk utprøvning} effekt og sikkerhet ved bruk av de nye perorale antikoagulantia. Studiene omhandler profylakse mot postoperativ trombose etter hofte- og knekirurgi (3-13), profylakse mot hjerneslag og systemiske embolier hos padær til klaffefeil (ikke-valvulær atrieflimmer) (14-16), behandling av akutt dyp venetrombose og/eller lungeembolisme (17-19), sekundærprofylakse etter venøs trombose (19-21), behandling av akutt koronorsykdom (22-24), og tromboseprofylakse hos indremedisinske pasienter $(25,26)$.

Et hovedprinsipp ved de kliniske utprøvningene har vært å vise at den kliniske effekten av de nye perorale antikoagulasjonsmidlene ikke er dårligere enn nåværende behandling med warfarin og/eller lavmolekylært heparin. Dette prinsippet kalles «non-inferiority» og brukes ofte i studier med aktive kontrollpersoner for å vise at en ny behandling ikke
Det er gjennomført store kliniske studier på sienter med atrieflimmer som ikke er sekun-

\author{
Waleed Ghanima \\ waleed.ghanima@so-hf.no \\ Medisinsk avdeling \\ Sykehuset Østfold \\ og \\ Oslo universitetssykehus
}

\section{Dan Atar}

Kardiologisk avdeling

Oslo universitetssykehus, Ullevål

\section{Per Morten Sandset}

Avdeling for blodsykdommer

Oslo universitetssykehus

Se også kunnskapsprøve

på www.tidsskriftet.no/quiz

Engelsk oversettelse på www.tidsskriftet.no

e-tab 2 og e-tab 3 finnes i Tidsskriftets

elektroniske utgaver

> Se også side 1906

\section{HOVEDBUDSKAP}

De nye perorale antikoagulasjonsmidlene hemmer aktivert koagulasjonsfaktor II (trombin) eller aktivert faktor $\mathrm{X}$ direkte

Bruken må begrenses til godkjente indikasjoner og medikamentinteraksjoner må sjekkes før oppstart

Monitorering av antikoagulasjonseffekten er ikke nødvendig på grunn av forutsigbart dose-respons-forhold

Pasientene må følges opp for å vurdere etterlevelse, nyrefunksjon og blødningsrisiko

God etterlevelse er viktig for å oppnå ønsket effekt 
har dårligere effekt eller lavere sikkerhet den etablerte. Siden det ikke er mulig å vise at de to behandlingene har eksakt samme effekt, betraktes altså behandlingen som «ikke dårligere» (non-inferior) hvis forskjellen i effekt ligger innenfor en predefinert margin.

\section{Dabigatran etexilate}

De kliniske studiene der man har har undersøkt postoperativ tromboseprofylakse med dabigatran etter gjennomgått hoftekirurgi $(9,11)$ eller kneleddskirurgi $(4,10)$ har til sammen omfattet over 10000 pasienter. Dabigatran ble gitt i 28-35 dager etter hofteleddskirurgi og i 6-10 dager etter kneleddskirurgi og sammenliknet med enoksaparin. I disse studiene var dabigatran ikke dårligere enn enoksaparin (40 mg daglig) til å forebygge asymptomatisk eller symptomatisk venøs trombose og dødsfall. Dabigatran var derimot dårligere enn enoksaparin dosert $30 \mathrm{mg} \times 2$ daglig - en dosering som hovedsakelig brukes i USA (4). Det var ingen signifikante forskjeller i forekomst av alvorlige blødninger mellom dabigatran og enoksaparin i disse studiene.

Hos pasienter med ikke-valvulær atrieflimmer ble dabigatran sammenliknet med warfarin som profylakse mot hjerneslag og systemisk embolisme (15). Dabigatran ble gitt i to ulike doser (e-tab 2) (14-16, 27). Den høye dosen $(150 \mathrm{mg} \times 2)$ ga signifikant redusert forekomst av endepunktene og tilnærmet lik blødningsrisiko sammenliknet med warfarin. Den lave dosen $(110 \mathrm{mg} \times 2)$ var ikke dårligere enn warfarin $i$ forebygging av hjerneslag og systemisk embolisme og ga samtidig signifikant færre blødninger enn warfarin (15). Det var færre livstruende og intrakraniale blødninger i dabigatrangruppene enn i warfaringruppen, men flere gastrointestinale blødninger i gruppen med høy dose dabigatran.

Hos pasienter med akutt dyp venetrombose og/eller lungeembolisme ble dabigatran sammenliknet med warfarin etter at alle pasientene initialt hadde fått behandling med enoksaparin i 5-10 dager. Dabigatranbehandling var ikke dårligere enn warfarinbehandling (17). Dabigatran har også vært prøvd ut i to studier som langtidsprofylakse etter initial behandling for akutt venøs trombose (18). I den ene studien (RE-SONATE) ble dabigatran sammenliknet med placebo etter initialt 6-18 måneders konvensjonell antikoagulasjonsbehandling. Dabigatran ga signifikant lavere risiko for residiv sammenliknet med placebo, men uten økning i alvorlige blødninger. Den andre studien (RE-MEDY) hadde en aktiv kontrollgruppe som fikk warfarin, og

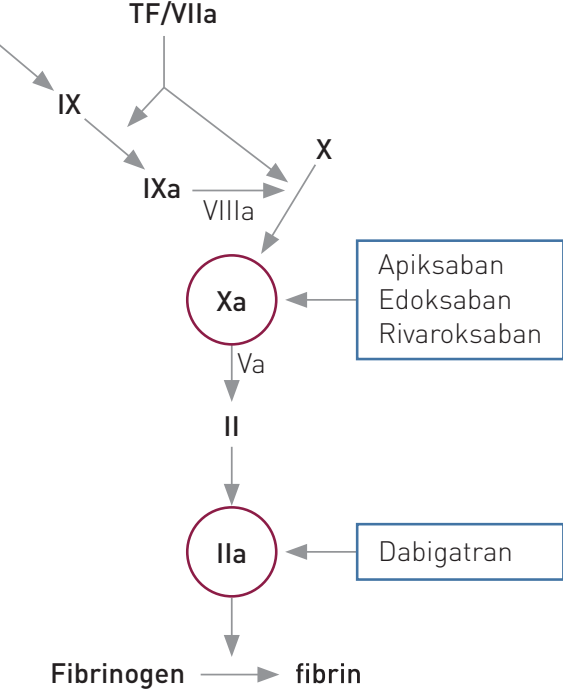

Figur 1 Koagulasjonssystemet aktiveres når vevsfaktor (tissue factor. TF) kommer i kontakt med blodet og bindes til koagulasjonsfaktor VII. Faktor VII er et proenzym som aktiveres til VIla når VII bindes til TF. TFNIla-komplekset aktiverer så koagulasjonen og fører til danning av faktor Xa og faktor lla (trombin). De nye perorale antikoagulantia er små molekyler som hemmer enzymaktiviteten til faktor Xa eller trombin. Det er utviklet tre faktor Xa-hemmere-apiksaban, edoksaban og rivaroksaban - og en trombinhemmer (dabigatran). Edokasban er foreløpig ikke godkjent i Norge

Tabell 1 De viktigste egenskapene til de nye antikoagulasjonsmedikamentene. Tabellen er utarbeidet av forfatterne basert på heftet Informasjon om de nye perorale antikoagulasjonsmidlene dabigatran, rivaroksaban og apiksaban (2)

\begin{tabular}{|c|c|c|c|}
\hline Medikament & Dabigatran etexilate ${ }^{1}$ & Apiksaban & Rivaroksaban \\
\hline Målenzym & Trombin & Faktor Xa & Faktor Xa \\
\hline Biotilgjengelighet (\%) & $6-7$ & 50 & $\begin{array}{c}80-100 \text { (ved dose } 10 \mathrm{mg} \text { ) } \\
66 \text { (ved dose } 20 \mathrm{mg} \text { ) }\end{array}$ \\
\hline Proteinbinding $(\%)$ & 35 & 87 & $92-95$ \\
\hline Tid til maksimal konsentrasjon (t) & $1-2$ & $3-4$ & $2-4$ \\
\hline Andel som metaboliseres (\%) & 10 & 25 & $60-70$ \\
\hline CYP-metabolisme & Ingen & CYP3A4 & CYP3A4 \\
\hline P-glykoprotein (P-gp) & Er substrat & Er substrat & Er substrat \\
\hline Utskilling i urinen (\%) & 80 & 272 & $67^{3}$ \\
\hline \multicolumn{4}{|l|}{ Halveringstid ved ulik GFR (t) } \\
\hline$>80 \mathrm{ml} / \mathrm{min}$ & 14 & 15 & 8 \\
\hline $50-79 \mathrm{ml} / \mathrm{min}$ & 17 & 15 & 9 \\
\hline $30-49 \mathrm{ml} / \mathrm{min}$ & 19 & 17 & 9 \\
\hline$<30 \mathrm{ml} / \mathrm{min}$ & 28 & 17 & 10 \\
\hline Varighet av antikoagulasjonsvirkning (dager) & $\begin{array}{c}1-3 \\
\text { Avhengig av GFR }\end{array}$ & $1-2$ & $1-2$ \\
\hline
\end{tabular}

${ }^{1}$ Dabigatran er den aktive substansen. Etexilategruppen er nødvendig for opptak i tarm, men spaltes av i leveren etter absorpsjon

2 Resten metaboliseres eller skilles uendret ut i tarm

${ }^{3}$ Halvparten uendret og halvparten metabolisert 
Tabell 4 Foreløpige godkjente indikasjoner for nye perorale antikoagulantia (2). Ved behov for antikoagulasjonsbehandling for tilstander der disse medikamentene ikke har indikasjon, skal warfarin eller hepariner anvendes

\begin{tabular}{lccc}
\hline & Dabigatran \\
Indikasjon & etexilate & Apiksaban & Rivaroksaban \\
Ikke-valvulær atrieflimmer & $\mathrm{Ja}$ & $\mathrm{Ja}$ & $\mathrm{Ja}$ \\
Postoperativ profylakse ved kne- og hoftekirurgi & $\mathrm{Ja}$ & $\mathrm{Ja}$ & $\mathrm{Ja}$ \\
Dyp venetrombose - akutt & $\mathrm{Nei}$ & $\mathrm{Nei}$ & $\mathrm{Ja}$ \\
Lungeembolisme - akutt & $\mathrm{Nei}$ & $\mathrm{Nei}$ & $\mathrm{Ja}$ \\
Venøs trombose - sekundærprofylakse & $\mathrm{Nei}$ & $\mathrm{Nei}$ & $\mathrm{Ja}$ \\
\hline
\end{tabular}

deltakerne ble randomisert etter 3-12 måneder med konvensjonell antikoagulasjonsbehandling (20). Her var dabigatran ikke dårligere enn warfarin, men førte til færre blødninger (e-tab 3) (17-21, 28).

Ved den kliniske utprøvningen av dabigatran har halvparten av alle blødningene vært i gastrointestinaltractus. Dyspepsi var vanligere i gruppen som fikk dabigatran (17).

\section{Rivaroksaban}

De kliniske studiene der man har undersøkt postoperativ tromboseprofylakse med rivaroksaban etter gjennomgått hofte- eller kneleddskirurgi har til sammen omfattet 12500 pasienter $(3,5,12,13)$. Rivaroksabanprofylakse var i alle studiene signifikant bedre enn profylakse med enoksaparin. Det var ingen signifikante forskjeller i forekomst av alvorlige blødninger, selv om det for alle studiene sett under ett var en tendens til økning $i$ antallet alvorlige blødninger (1). Forlenget tromboseprofylakse med rivaroksaban i 31-39 dager var signifikant bedre enn 10-14 dagers profylakse med enoksaparin, som har vært vanlig praksis etter hofteleddskirurgi (3).

Hos pasienter med ikke-valvulær atrieflimmer var behandling med rivaroksaban ikke dårligere enn warfarinbehandling til forebygging av slag og systemisk embolisme (14), og det var ingen signifikant forskjell i forekomst av alvorlige blødninger, selv om det var færre intrakraniale og dødelige blødninger i rivaroksabangruppen (e-tab 2) (14).

Hos pasienter med akutt lungeembolisme $\mathrm{med} / \mathrm{uten}$ dyp venetrombose (18) og dyp venetrombose uten lungeembolisme (19) var behandling med rivaroksaban ikke dårligere enn konvensjonell behandling (2). Rivaroksaban har også vært prøvd ut som langtidsprofylakse etter konvensjonell antikoagulasjonsbehandling for akutt dyp venetrombose og/eller lungeembolisme og ga signifikant lavere risiko for residiv sammenliknet med placebo, uten signifikant høyere forekomst av alvorlige blødninger (19).

Ved akutt koronarsyndrom førte lavdose rivaroksaban gitt som tilleggsbehandling til konvensjonell behandling med platehemmere til reduksjon i kardiovaskulær mortalitet, hjerteinfarkt eller slag sammenliknet med tilleggsbehandling med placebo. Men behandlingen førte samtidig til økt forekomst av alvorlige, men ikke-dødelige blødninger (23).

Som tromboseprofylakse hos akutt syke innlagte indremedisinske pasienter med høy risiko for venøs trombose var rivaroksaban ikke dårligere enn enoksaparin, men førte til signifikant flere blødninger (26).

\section{Apiksaban}

I studiene der man har undersøkt profylakse med apiksaban mot postoperativ trombose etter hofte- og knekirurgi har det totalt vært inkludert ca. 11000 pasienter (6-8). Profylakse med apiksaban var ikke dårligere enn enoksaparin $40 \mathrm{mg} \times 1(7,8)$, men var dårligere enn enoksaparin $30 \mathrm{mg} \times 2$ daglig (6). Det ble ikke påvist forskjeller i blødningsrisiko i disse studiene.

Hos pasienter med ikke-valvulær atrieflimmer ga behandling med apiksaban signifikant færre tilfeller av slag og systemisk embolisme, og lavere totalmortalitet, enn behandling med warfarin, og det var signifikant færre alvorlige blødninger (27) (e-tab 2). I en annen studie var apiksaban signifikant bedre enn acetylsalisylsyre som profylakse mot slag eller systemisk embolisme hos pasienter som ikke var egnet for behandling med warfarin. Det var ingen forskjell i forekomst av alvorlige blødninger (16).

Hos pasienter med akutt dyp venetrombose og/eller lungeembolisme var behandling med apiksaban ikke dårligere enn konvensjonell behandling (28). Ved langtidsprofylakse etter initial antikoagulasjonsbehandling førte apiksaban til signifikant reduksjon i risikoen for residiv av venøs trombose sammenliknet med placebo, uten signifikant økt blødningsrisiko (21). Apiksaban er foreløpig ikke godkjent for behandling av venøs trombose.

Apiksaban har også vært prøvd ut som tromboprofylakse hos akutt syke innlagte indremedisinske pasienter med høy risiko for venøs trombose (25) og i kombinasjon med platehemmere ved akutt koronarsyndrom (24). Apiksaban var ikke bedre enn henholdsvis enoksaparin eller placebo i disse to studiene, det var tvert imot økt forekomst av blødninger.

\section{Tolking av fase 3-studiene}

Studiene har vist at de nye antikoagulasjonsmedikamentene enten er «ikke dårligere» (non-inferior) eller bedre enn konvensjonell behandling for indikasjonene tromboseprofylakse etter hofte- og kneleddskirurgi, forebygging av slag og systemisk embolisme hos pasienter med ikke-valvulær atrieflimmer, behandling av akutt venøs trombose, selv om kun rivaroksaban er godkjent for denne indikasjonen foreløpig. I disse studiene har forekomsten av alvorlige blødninger vært lik eller lavere enn ved konvensjonell antikoagulasjonsbehandling. Ved atrieflimmer har alle de de tre medikamentene vist signifikant lavere forekomst av intrakraniale blødninger enn warfarin $(14,15,27)$.

Etter avsluttet antikoagulasjonbehandling for akutt venøs trombose er det betydelig risiko for residiv, men fordi warfarin også medfører betydelig blødningsrisiko er behandlingen ofte tidsbegrenset, særskilt etter første episode. Sekundærprofylakse med nye antikoagulasjonsmedikamenter kan redusere risikoen for residiv med ca. $70-80 \%$ sammenliknet med placebo, uten at det er betydelig økning antallet $\mathrm{i}$ alvorlige blødninger (19-21).

Studiene gjennomført med henholdsvis standarddose dabigatran, standarddose apiksaban og lavdose rivaroksaban ved akutt koronarsykdom har vist sprikende resultater hva gjelder klinisk effekt og blødningsrisiko (22-24). Det er kun lavdose rivaroksaban som har gitt lavere mortalitet uten signifikant $ø$ kning av antall alvorlige blødninger (23). Forlenget tromboseprofylakse med apiksaban eller rivaroksaban hos akutt syke innlagte indremedisinske pasienter ga signifikant høyere blødningsrater og dermed ingen gevinst sammenliknet med ti dagers behandling med enoksaparin $(25,26)$.

Alle kliniske studier på disse medikamentene er gjennomført uten dosejustering i forhold til antikoagulasjonseffekt. Det betyr at behandling med dabigatran, rivoksaban og apiksaban kan gjennomføres uten monitorering av antikoagulasjonseffekten. Imidlertid har alle tre relativt kort halveringstid. Manglende etterlevelse (compliance) er derfor et potensielt problem når disse medikamentene skal brukes i praksis. Pasientene som blir med i kliniske studier er som regel motiverte og blir grundig fulgt opp, noe som sannsynligvis fører til bedre etterlevelse. Det vil 
Tabell 5 Viktige praktiske råd for bruk av nye perorale antikoagulantia. Rådene er basert på egne erfaringer med bruk av disse medikamentene samt gjennomgang og tolking av litteraturen

Må brukes på godkjente indikasjon

\section{Kontraindikasjoner} og forsiktighetsregler
Medikamentene skal kun brukes på godkjente indikasjoner. Disse varierer for de ulike preparatene Anbefalt dosering varierer avhengig av indikasjon, nyrefunksjon og pasientens alder

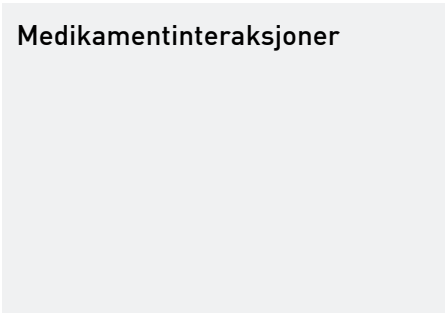

Pasientinformasjon/oppfølging

\section{Håndtering av alvorlige} blødninger

\section{Overgang fra andre} antikoagulasjonsmidler/ kortvarig behandlingsavbrudd

\author{
Medikamentene må ikke gis ved: \\ - mekanisk hjerteventil \\ - valvulær atrieflimmer \\ - graviditet/amming \\ - aktive blødninger \\ - alvorlig nyresvikt \\ - nedsatt leverfunksjon med koagulopati
}

Vær oppmerksom på komorbide tilstander som øker risikoen for blødning som nedsatt nyre- og leverfunksjon, trombocytopeni og alkoholisme

Unngå medikamentene der det er mistanke om dårlig etterlevelse

Kontroller nivå av hemoglobin, trombocytter, ALAT, bilirubin, kreatinin og INR før oppstart

Sjekk interaksjoner med pasientens andre medikamenter på http://interaksjoner.no/

Unngå bruk av nye antikoagulasjonsmedikamenter hvis pasienten bruker medikamenter som hemmer eller induserer P-gp eller CYP3A4.

- Eksempler på hemmere av P-gp og/eller CYP3A4 som gir økt blødningsfare: amiodaron, verapamil' ${ }^{1}$, kinidin $^{1}$, ketokonazol/voriconazole 1 , klaritromycin/erytromycin og hivmidler ${ }^{1}$

- Eksempler på medikamenter som induserer P-pg og/eller CYP3A4 og gir redusert effekt: rifampicin?, johannesurt ${ }^{1}$, karbamazepin $^{1}$, fenytoin ${ }^{1}$

Nye perorale antikoagulantia skal ikke kombineres med platehemmere (med mindre kombinasjonen er indisert), ikke-steroide antiinflammatoriske midler eller andre antikoagulantia

Pasienten må utstyres med pasientkort og må informeres om viktigheten av

- god etterlevelse

- håndtering av gjenglemt dose

- mulige interaksjoner

- at medikamentene er kontraindisert ved svangerskap.

Spør ved kontrollene om: etterlevelse og eventuelle blødninger.

Arlig kontroll av Hb, kreatinin/GFR - hver 3.-6. måned ved nedsatt nyrefunksjon

Seponere medikamentene og sikre lokal hemostase

Medikamentell reversering ved livstruende blødninger

Ved skifte fra warfarin til de nye antikoagulasjonsmedikamentene varierer anbefalingene for INR-nivå mellom medikamentene. Se Felleskatalogen for nøyaktig INR-nivå

Nye perorale antikoagulantia kan påstartes etter 12-24 timer fra siste dose av lavmolekylært heparin

Ved planlagt kirurgi holder det å nulle ut nye perorale antikoagulantia i $24-48$ timer før planlagt operasjon, avhengig av inngrepets omfang og pasientens nyrefunksjon

Rapportering

Indikerer moderat til sterk interaksjon

også bidra til raskere identifisering og behandling av interkurrente tilstander som kan oppstå under behandlingen.

Ett eksempel er forverring av nyrefunksjon/utvikling av nyresvikt, som igjen kan forårsake økt medikamentkonsentrasjon og fare for blødninger. Forventet dårlig pasientetterlevelse var et av eksklusjonskriteriene i de fleste studiene, i tillegg til lett til moderat forhøyede levertransaminaser og bilirubin og ukontrollert hypertensjon. Vi har derfor lite kunnskap om pasienter som tilhører en av disse gruppene. Det samme gjelder pasienter med kreftsykdom. Høy alder var ikke et eksklusjonskriterium, men det er begrenset klinisk erfaring med pasienter over 75 år.

\section{Praktiske råd}

Disse rådene er basert på preparatomtalene (summary of product charactistics, SPC), som kan hentes på Legemiddelverkets nett- sider for de ulike formuleringene for hvert enkelt preparat (vår avlesningsdato 3.7. 2013) (29), og forfatternes erfaring og andre informasjonskilder (2). I tabell 4 oppsummeres indikasjonene for de ulike medikamentene, og i tabell 5 oppsummeres praktiske råd vedrørende oppstart og oppfølging.

\section{Medikamentene må kun brukes \\ på godkjente indikasjoner}

Det er viktig at leger setter seg nøye inn i preparatomtalen før bruk for informasjon om indikasjoner, dosering og forsiktighetsregler. Alle de tre medikamentene har tromboseprofylakse etter kne- og hofteleddskirurgi som godkjent indikasjon. Alle tre har også ikkevalvulær atrieflimmer som godkjent indikasjon (2). Foreløpig er det kun rivaroksaban som er godkjent for akutt behandling av dyp venetrombose og/eller lungeembolisme og for sekundærprofylakse etter venøs trombose.
Kontraindikasjoner og forsiktighetsregler Medikamentene må ikke gis til pasienter med mekanisk hjerteventil og valvulær atrieflimmer (alvorlig postrevmatisk hjerteklaffefeil) eller til gravide og ammende kvinner. De er ikke blitt prøvd ut for behandling av barn og heller ikke ved akutt venøs trombose hos pasienter med kreftsykdom. Pasienter med en glomerulær filtrasjonshastighet (GFR) på $<30 \mathrm{ml} / \mathrm{min}$ skal ikke ha dabigatran, mens rivaroksaban og apiksaban ikke skal gis til pasienter med GFR $<15 \mathrm{ml} / \mathrm{min}$. Til slike pasienter (med unntak av gravide) anbefaler vi heller konvensjonell antikoagulasjonsbehandling med warfarin.

De nye perorale antikoagulantia skal heller ikke gis til pasienter med alvorlig nedsatt leverfunksjon og tegn til koagulopati. Nyrefunksjon og leverstatus må derfor sjekkes før eventuell oppstart. Det bør utvises forsiktighet ved forskrivning av midlene til pa- 
sienter med forventet dårlig etterlevelse. Vi anbefaler dosereduksjon hos eldre pasienter (> 80 år), blant annet pga. redusert nyrefunksjon og generell økt blødningsrisiko.

\section{Medikamentinteraksjoner}

Dabigatran, rivaroksaban og apiksaban bør helst ikke brukes der det er betydelig fare for interaksjon med andre medikamenter (tabell 5). De skal normalt heller ikke kombineres med andre antikoagulantia, platehemmere eller ikke-steroide antiinflammatoriske midler.

\section{Pasientinformasjon og oppfølging}

Grundig informasjon til pasientene er viktig. De må utstyres med pasientkort med informasjon om dosering og indikasjon. Pasienten må regelmessig gjøres oppmerksom på viktigheten av etterlevelse og at han/hun ikke er beskyttet hvis 1-2 doser ikke er tatt. Det er viktig å understreke at medikamentet skal tas regelmessig til samme tidspunkt på døgnet.

Selv om det ikke behøves laboratoriemonitorering av koagulasjonseffekten, er det fortsatt viktig at pasientene jevnlig følges opp for å vurdere blødningsrisiko, nyrefunksjon (særskilt ved bruk av dabigatran hos eldre) og etterlevelse.

\section{Håndtering av alvorlige blødninger}

Det kan bli behov for reversering av antikoagulasjonseffekten ved alvorlige blødninger, særlig hjerneblødninger, ved livstruende blødninger og ved behov for akuttkirurgi. Foreløpig finnes det ingen spesifikke antidoter som kan reversere effekten av medikamentene. Ved blødning må medikamentene seponeres og generelle tiltak iverksettes, som lokal hemostase og blodtransfusjon. Grunnet den korte halveringstiden vil effekten være borte i løpet av et halvt til ett døgn (30). Dersom blødningen oppstår etter én halveringstid, vil medikamenteffekten normalt være så lav at det ikke blir behov for antidot (30).

Kull er spesielt effektivt mot dabigatran og må gis ved overdosering eller blødning hvis dosen er tatt innenfor de siste to timer (31). Siden dabigatran ikke er proteinbundet, kan mesteparten fjernes med dialyse (31) Ved alvorlige blødninger kan det bli nødvendig med medikamentell reversering av effekten. Protrombinkomplekskonsentrat bør gis, anbefalt dose 30-50 E/kg kroppsvekt (29). Aktivert protrombinkomplekskonsentrat på 50-80 E/kg og rekombinant FVIIa (rFVIIa) er trolig den mest effektive behandlingen og må vurderes ved alvorlige blødninger (2). Vi anbefaler at alle sykehus har aktivert protrombinkomplekskonsentrat og eventuelt rekombinant FVIIa i beredskap.
Overgang fra andre antikoagulasjonsmidler eller kortvarig behandlingsavbrudd

Dersom det foreligger indikasjon for å skifte fra warfarin, kan overgangen til de nye antikoagulasjonsmedikamentene skje når INRnivået er $\mathrm{i}$ et definert område avhengig av tilstanden og preparatet (29). Ved skifte fra lavmolekylært heparin kan behandling med nye perorale antikoagulantia startes etter 12-24 timer fra siste dose (29).

Ved planlagt kirurgi holder det vanligvis å nulle ut de nye perorale antikoagulantia i 24-48 timer før planlagt operasjon, avhengig av pasientens nyrefunksjon, inngrepets omfang og forventet blødningsrisiko. Etter operasjonen kan medikamentbehandlingen startes igjen når hemostasen er sikret og blødningsfaren er over (2).

\section{Måling av antikoagulasjonseffekt}

Det kan oppstå behov for måling av antikoagulasjonseffekten i noen situasjoner ved behandlingssvikt, ved akuttkirurgi og ved blødninger (32). De vanlige koagulasjonstestene som INR og aktivert partiell tromboplastintid (APTT) kan bli påvirket av disse medikamentene. Imidlertid viser ingen av disse en lineær sammenheng med medikamentkonsentrasjonen og de kan dermed ikke brukes til måling av antikoagulasjonseffekten. APTT-varigheten forlenges av dabigatran, og verdier $>90$ sekunder kan tyde på overdosering, mens verdier mellom 70 sekunder og 90 sekunder tyder på optimal antikoagulasjonseffekt.

Spesifikke koagulasjonstester for nøyaktig bestemmelse av koagulasjonseffekten, som «ekarin koagulasjonstid» for dabigatran eller anti-FXa som er kalibrert for måling av rivaroksaban og apiksaban (ikke for lavmolekylært heparin), er foreløpig ikke tilgjengelige i Norge.

\section{Rapportering av uønskede hendelser}

Det er viktig med overvåking og rapportering av uventede effekter av behandlingen og av legemiddelinteraksjoner.

\section{Konklusjon}

Tre nye antikoagulasjonsmedikamenter har nylig fått markedsføringstillatelse i Norge. Både effekt og sikkerhet er godt dokumentert i kliniske studier for de mest vanlige indikasjoner. Det er viktig å begrense bruken av disse medikamentene til godkjente indikasjoner og til pasienter med god etterlevelse. Selv om det ikke er behov for monitorering av koagulasjonseffekten, bør pasientene fortsatt følges opp regelmessig for å avdekke tilstander som kan føre til endringer i forventet effekt eller sikkerhet.

\section{Waleed Ghanima (f. 1964)}

er spesialist i indremedisin og i blodsykdommer og førsteamanuensis.

Forfatter har fylt ut ICMJE-skjemaet og oppgir følgende interessekonflikter: Han er medlem av vitenskapelig rådgivningsgruppe og har mot tatt foredragshonorar/reisestøtte fra Boehringer-Ingelheim og Bayer.

\section{Dan Atar (f. 1959)}

er professor i kardiologi og avdelingsoverlege. Han har vært medforfatter på både 2010- og 2012-utgaven av ESC-guidelines for atrieflimmer.

Forfatter har fylt ut ICMJE-skjemaet og oppgir følgende interessekonflikter: Han har mottatt foredragshonorar/reisestøtte fra BoehringerIngelheim, BMS/Pfizer, Bayer og NycomedTakeda.

\section{Per Morten Sandset (f. 1956)}

er spesialist i blodsykdommer, forskningsleder og professor. Han er sjefredaktør av Thrombosis Research og leder arbeidet med de nasjonale retningslinjene for antitrombotisk behandling. Forfatter har fylt ut ICMJE-skjemaet og oppgir følgende interessekonflikter: Han har mottatt foredragshonorar fra Boehringer-Ingelheim, Bayer og BMS/Pfizer.

\section{Litteratur}

1. Garcia D, Libby E, Crowther MA. The new ora anticoagulants. Blood 2010; 115: 15-20.

2. Sandset PM, Dalbak W, Aamodt L et al. Informasjon om de nye perorale antikoagulasjonsmidlene dabigatran, rivaroksaban og apiksaban. Oslo: Helsedirektoratet, 2013.

3. Kakkar AK, Brenner B, Dahl OE et al. Extended duration rivaroxaban versus short-term enoxaparin for the prevention of venous thromboembolism after total hip arthroplasty: a double-blind, randomised controlled trial. Lancet 2008; 372: 31 -9

4. Ginsberg JS, Davidson BL, Comp PC et al. Oral thrombin inhibitor dabigatran etexilate vs North American enoxaparin regimen for prevention of venous thromboembolism after knee arthroplasty surgery. J Arthroplasty 2009; 24: 1-9.

5. Turpie AG, Lassen MR, Davidson BL et al. Rivaroxaban versus enoxaparin for thromboprophylaxis after total knee arthroplasty (RECORD4): a randomised trial. Lancet 2009; 373: 1673-80.

6. Lassen MR, Raskob GE, Gallus A et al. Apixaban or enoxaparin for thromboprophylaxis after knee replacement. N Engl J Med 2009: 361: 594-604.

7. Lassen MR Raskob GE Gallus A et al. Apixaban versus enoxaparin for thromboprophylaxis after knee replacement (ADVANCE-2): a randomised double-blind trial. Lancet 2010; 375: 807-15.

8. Lassen MR, Gallus A, Raskob GE et al. Apixaban versus enoxaparin for thromboprophylaxis after hip replacement. N Engl J Med 2010; 363: 2487-98.

9. Eriksson BI, Dahl OE, Rosencher N et al. Dabigatran etexilate versus enoxaparin for prevention of venous thromboembolism after total hip replacement: a randomised, double-blind, non-inferiority trial. Lancet 2007; 370: 949-56.

10. Eriksson BI, Dahl OE, Rosencher $\mathrm{N}$ et al. Oral dabigatran etexilate vs. subcutaneous enoxaparin for the prevention of venous thromboembolism 
after total knee replacement: the RE-MODEL randomized trial. J Thromb Haemost 2007; 5: 2178-85.

11. Eriksson BI, Dahl OE, Huo MH et al. Oral dabigatran versus enoxaparin for thromboprophylaxis after primary total hip arthroplasty (RE-NOVATE ${ }^{\prime *}$ ). A randomised, double-blind, non-inferiority trial. Thromb Haemost 2011; 105: 721-9.

12. Eriksson BI, Borris LC, Friedman RJ et al. Rivaroxaban versus enoxaparin for thromboprophylaxis after hip arthroplasty. N Engl J Med 2008; 358: 2765-75.

13. Lassen MR, Ageno W, Borris LC et al. Rivaroxaban versus enoxaparin for thromboprophylaxis after total knee arthroplasty. N Engl J Med 2008; 358 2776-86.

14. Patel MR, Mahaffey KW, Garg J et al. Rivaroxaban versus warfarin in nonvalvular atrial fibrillation. N Engl J Med 2011; 365: 883-91.

15. Connolly SJ, Ezekowitz MD, Yusuf S et al. Dabigatran versus warfarin in patients with atrial fibrillation. N Engl J Med 2009; 361: 1139-51.

16. Connolly SJ, Eikelboom J, Joyner C et al. Apixaban in patients with atrial fibrillation. N Engl J Med 2011; 364: 806-17

17. Schulman S, Kearon C, Kakkar AK et al. Dabigatran versus warfarin in the treatment of acute venous thromboembolism. N Engl J Med 2009; 361: 2342-52

18. Büller HR, Prins MH, Lensin AW et al. Oral rivaroxaban for the treatment of symptomatic pulmonary embolism. N Engl J Med 2012; 366: 1287-97.

19. Bauersachs R, Berkowitz SD, Brenner B et al. Oral rivaroxaban for symptomatic venous thromboembolism. N Engl J Med 2010; 363: 2499-510.

20. Schulman S, Kearon C, Kakkar AK et al. Extended use of dabigatran, warfarin, or placebo in venous thromboembolism. N Engl J Med 2013; 368: $709-18$.

21. Agnelli G, Buller HR, Cohen A et al. Apixaban for extended treatment of venous thromboembolism. N Engl J Med 2013; 368: 699-708.

22. Oldgren J, Budaj A, Granger CB et al. Dabigatran vs. placebo in patients with acute coronary syn- dromes on dual antiplatelet therapy: a randomized, double-blind, phase II trial. Eur Heart J 2011 . 32: $2781-9$.

23. Mega JL, Braunwald E, Wiviott SD et al. Rivaroxaban in patients with a recent acute coronary syndrome. N Engl J Med 2012; 366: 9-19.

24. Alexander JH, Lopes RD, James S et al. Apixaban with antiplatelet therapy after acute coronary syndrome. N Engl J Med 2011; 365: 699-708.

25. Goldhaber SZ, Leizorovicz A, Kakkar AK et al. Apixaban versus enoxaparin for thromboprophylaxis in medically ill patients. N Engl J Med 2011; 365: 2167-77

26. Cohen AT, Spiro TE, Büller HR et al. Rivaroxaban for thromboprophylaxis in acutely ill medical patients. N Engl J Med 2013; 368: 513-23.

27. Granger CB, Alexander JH, McMurray JJ et al. Apixaban versus warfarin in patients with atrial fibrillation. N Engl J Med 2011; 365: 981-92.

28. Agnelli G, Buller HR, Cohen A et al. Oral apixaban for the treatment of acute venous thromboembolism. N Engl J Med 2013. E-publisert 1.7.

29. Statens legemiddelverk. www.legemiddelverket.no (25.8.2013).

30. Ageno W, Gallus AS, Wittkowsky A et al. Oral anticoagulant therapy: antithrombotic therapy and prevention of thrombosis, 9th ed: American College of Chest Physicians evidence-based clinical practice guidelines. Chest 2012; 141 (suppl 2): e44S-88S.

31. Kaatz S, Kouides PA, Garcia DA et al. Guidance on the emergent reversal of oral thrombin and factor $X_{a}$ inhibitors. Am J Hematol 2012; 87 (suppl 1): S141-5.

32. Garcia D, Barrett YC, Ramacciotti E et al. Laboratory assessment of the anticoagulant effects of the next generation of oral anticoagulants. J Thromb Haemost 2013; 11: 245-52.

Mottatt 27.9. 2012, første revisjon innsendt 26.2. 2013, godkjent 25.8. 2013. Redaktør Merete Kile Holtermann. 